\title{
Spatio-temporal changes in gut contents and stable isotopes in two deep Mediterranean pandalids: influence on the reproductive cycle
}

\author{
Emanuela Fanelli*, Joan E. Cartes \\ Institut de Ciències del Mar de Barcelona, Consejo Superior de Investigaciones Cientificas, Passeig Marítim \\ de La Barceloneta 37-49, 08003 Barcelona, Spain
}

\begin{abstract}
The feeding habits of the 2 Plesionika species occurring around the Balearic Islands (western Mediterranean) were examined. Samples were taken with a bottom trawl from depths between 247 and 752 m from August 2003 to June 2004 at 2 sites (Cabrera and Sóller) off the island of Mallorca. Both species preferentially exploited mesopelagic resources but the shallower living $P$. heterocarpus, which inhabits the shelf-slope break, also consumed benthic organisms (e.g. polychaetes, bivalves, tanaids). Spatio-temporal changes were evident in the diet of the 2 pandalids. In $P$. heterocarpus, 2 seasonal groups were revealed by nMDS analysis, one summer-autumn, the other winter-spring. Differences in prey consumption were observed between Cabrera and Sóller samples, with a temporal shift in the dominance of some prey between the 2 areas. The diet of $P$. heterocarpus was significantly correlated with geographical (e.g. latitude, depth), chemico-physical variables (mainly those related to sediment characteristics) and biological features (e.g. maturity stages, sex) of the species. Correlation between percentage of mature females and caloric content of prey in the stomach did not show any clear seasonal pattern; also trophic level did not change throughout the year $\left(\delta^{15} \mathrm{~N}=7.87 \% \pm 0.17\right)$. Temporal changes in diet composition were stronger in the deeper pandalid $P$. martia and strictly related to its reproductive pattern. Three groups were revealed by multivariate analysis: (1) a summer group (August and September samples), (2) an autumn-winter group (November and February), characterized by high predation on gelatinous plankton, salps, hyperiids and pelagic molluscs and (3) a spring group, in which predation was directed to higher energy prey such as euphausiids and decapods. The higher percentage of mature females observed in spring was correlated with the increase in energy requirements in the pre-spawning period. Stable isotope analysis revealed a stronger seasonality for $P$. martia than for $P$. heterocarpus. An abrupt decrease in trophic level $\left(\delta^{15} \mathrm{~N}\right)$ and an analogous enrichment in $\delta^{13} \mathrm{C}$ values were observed in February. This trend may be related to various factors, among others a higher consumption of refractory material (e.g. marine snow) in winter, when mesopelagic resources are scarcer, changes in the whole zooplanktonic and suprabenthic communities due to phytodetritus input of low $\delta^{15} \mathrm{~N} / \mathrm{high} \delta^{13} \mathrm{C}$ values, and possible reproductive migration to deeper waters.
\end{abstract}

KEY WORDS: Pandalid shrimps · Diet · Reproduction · Seasonality · Environmental variables Benthopelagic fauna $\cdot$ Stable isotope analysis

Resale or republication not permitted without written consent of the publisher

\section{INTRODUCTION}

Pandalid shrimps belong to one of the most widely distributed and diversified families of marine shrimps comprising tropical and subtropical species distributed worldwide at shelf-slope break and bathyal depths
(Crosnier \& Forest 1973). Plesionika heterocarpus (Costa, 1871) and Plesionika martia (Milne Edwards, 1883) are demersal species with a wide geographical distribution in tropical and temperate ocean waters (Holthuis 1980). In the deep Mediterranean, P. heterocarpus is abundant at the shelf-slope break and the up- 
per slope (Abelló et al. 1988, Cartes et al. 1994), while $P$. martia is dominant in mid slope assemblages (from 300 to $800 \mathrm{~m}$ ) in the western (Carbonell \& Abelló 1998, Maynou \& Cartes, 2000) and eastern Mediterranean (Maiorano et al. 2002, Chilari et al. 2005); both species are absent in the northern and central Adriatic Sea.

Most studies performed on the biology of deep pandalids refer only to their depth distribution and importance within crustacean assemblages, e.g. in the western Mediterranean (Lagardére 1972, Abelló et al. 1988, Cartes et al. 1994) or the deep Atlantic (Lagardére 1977). Less information is available on reproductive biology and growth (Company \& Sardá 1997, Maiorano et al. 2002, Chilari et al. 2005), food consumption (Maynou \& Cartes, 1998), feeding habits (Lagardére 1972, Cartes 1993, Fanelli \& Cartes 2004), and particularly temporal changes and influence of prey availability. Considering the trophic habits of deep pandalid shrimps (Lagardére 1972, 1977, Cartes 1993), we can conclude that Plesionika species comprise an homogeneous trophic guild that mainly exploits pelagic resources such as euphausiids and mesopelagic decapods (e.g. Pasiphaea spp., Sergestidae, Cartes et al. 2002). $P$. heterocarpus also consumes infauna, particularly polychaetes (Lagardére 1977, Sánchez et al. 2006).

Despite a number of limitations (e.g. difficulties in the identification of soft or crushed prey, net feeding), stomach content analysis is the most reliable method for mass-balance modelling and studies of resource partitioning. Other methods more recently used in trophic ecology, such as pigment and isotopic analyses (Vander Zanden et al. 1997, Polunin et al. 2001), provide other information including the trophic level of consumers in trophic webs $\left(\delta^{15} \mathrm{~N}\right.$ analyses) and the origin (pelagic, benthic) of food assimilated $\left(\delta^{13} \mathrm{C}\right.$, pigment analyses). These methods are especially useful where traditional methods do not provide enough resolution, for example in gathering information on the trophic requirements of detritivore species (Howell et al. 2003). Detritivory (e.g. consuming mud and foraminiferans) and scavenging on fish remains have also been reported for Plesionika martia at the limits of its geographical distribution where the species is rare. Thus, a combination of methods (e.g. stomach contents and isotopy) is necessary to fully understand the role and trophic dynamics of Plesionika spp. in deep-water communities.

A number of Plesionika species with the same basic trophic role and with overlapping distributions can coexist in the same area, (Cartes et al. 1994). However, depth of maximum or optimal abundance, size distribution and prey exploited are often well partitioned among species (Cartes 1993, Fanelli \& Cartes 2004). Strong partitioning of food resources among neighbouring species (ecologically and taxonomically) is also found in deep water fish, e.g. in rattails (Macrouridae) (Macpherson 1981, Madurell \& Cartes 2006).

Temporal changes in the distribution and abundance of bathyal species are poorly known, although changes in the maximum/minimum depths of occurrence (Cartes et al. 2004) and size-related trends have been described. Larger-deeper trends have been described for Plesionika spp. (Morales-Nin et al. 2003) along the upper and middle slope in the deep Mediterranean, with smaller juveniles found associated with nepheloid layers close to the bottom (Puig et al. 2001). Most trophic studies, however, lack analysis of temporal changes in feeding activity, diet and the influence of environmental factors (e.g. prey availability; changes in productivity and oceanographic conditions) on the trophic requirements and life history of a species. As found for deep water fish in the Ionian Sea (Madurell \& Cartes 2005) and for the red shrimp Aristeus antennatus in the Balearic basin (Cartes et al. 2008), changes in both the availability and nature of prey may constitute the main factors affecting food consumption and probably the reproductive cycle of Plesionika species.

Beyond the description of diet and trophic position of Plesionika species (from stomach contents and stable isotope analyses), the objective of this study was to analyze possible relationships between environmental and trophic factors and the biological cycle of 2 dominant pandalid shrimps (Plesionika heterocarpus, and $P$. martia) inhabiting upper and mid-slope depths, respectively, around the Balearic Islands (Western Mediterranean). We give particular emphasis to seasonal and spatial changes and the influence of prey availability as possible causes of the trends observed.

\section{MATERIALS AND METHODS}

Shrimp sampling. Samples were collected during 6 bottom trawl surveys in the Western Mediterranean off Mallorca island (North-Western Mediterranean) (Fig. 1) in 2 different areas: around the Cabrera Archipelago (Algerian Basin) and off Sóller (Baleric Basin). A total of 72 hauls were made between 139 and $752 \mathrm{~m}$ from August 2003 to June 2004 within the framework of the IDEA project.

Plesionika specimens were collected from trawl hauls between 247 and $752 \mathrm{~m}$ (Appendix 1, available as MEPS Supplementary Material at: www.int-res.com/ articles/suppl/m355p219_app.pdf), carried out only during daylight periods. Shrimps were sampled with a commercial bottom trawl. The horizontal aperture of the gear was ca. $25.5 \mathrm{~m}(\mathrm{SD}=1.76 \mathrm{~m})$ and the vertical opening ca. $2.2 \mathrm{~m}$ (recorded using a SCANMAR system attached to the trawl). Cod-end mesh size was $40 \mathrm{~mm}$. Haul duration was always $1 \mathrm{~h}$ except in 


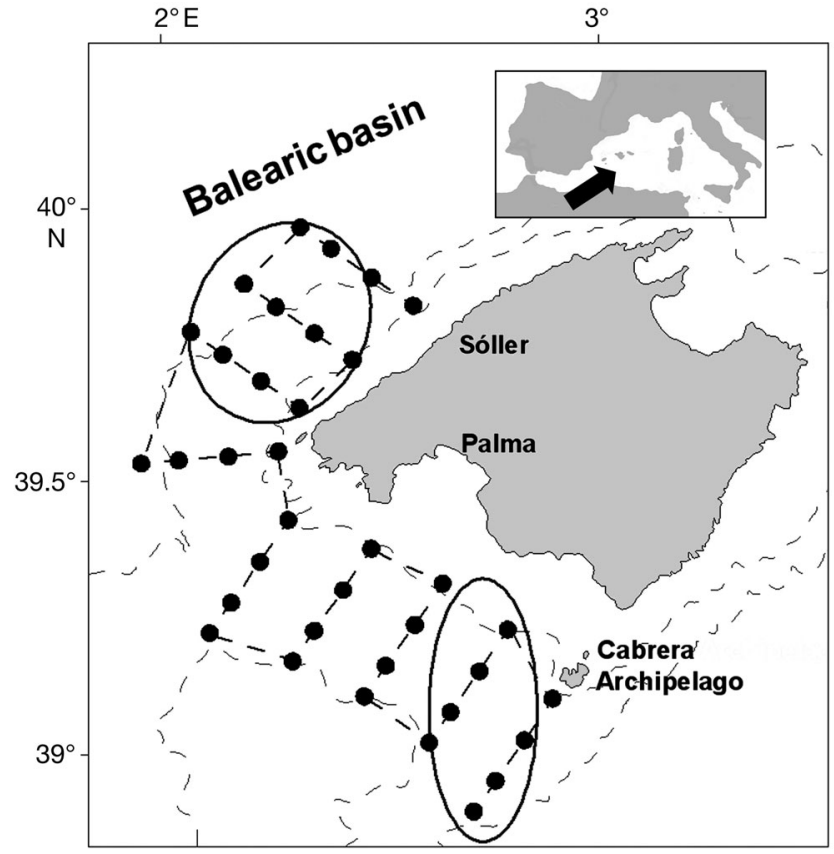

Fig. 1. The study area, indicating the shrimp sampling by trawling (large ovals), the suprabenthos-zooplankton sampling (large ovals) and the hydrographic stations $(\bullet)$

adverse weather conditions where the duration was reduced to $45 \mathrm{~min}$. Abundance (no. individuals $\mathrm{h}^{-1}$ ) and biomass $\left(\mathrm{g} \mathrm{h}^{-1}\right)$ were calculated after standardizing catches to $1 \mathrm{~h}$ of trawling.

Sample collection and processing. A total of 287 specimens of Plesionika heterocarpus and 794 of $P$. martia were collected and frozen at $-20^{\circ} \mathrm{C}$ in the laboratory (Appendix 1). For each specimen, the following data were recorded: (1) carapace length, CL, measured from the post-orbital socket to the posterior-median edge of the cephalothorax, to the nearest $\mathrm{mm}_{\text {; }}(2)$ body wet weight, WW, to the nearest $0.1 \mathrm{~g}_{i}$ (3) sex was determined under a binocular microscope, observing the shape of the endopodite in the first pair of pleopods and the presence or absence of the male appendix in the second pair of pleopods (King \& Moffitt 1984); (4) 4 stages of gonadal development in females were defined according to the relative intensity of the colour and size of the gonads, modifying the 5 stage range proposed by Company \& Sardá (1997) as follows: stage 1: immature females; stage 2: visible ovaries, no eggs; stage 3: ovaries occupied 30 to $50 \%$ of $\mathrm{CL}$, blue eggs; stage 4: ovaries occupied the whole cephalothorax cavity, blue or dark eggs. Stages 2 to 4 were mature.

The wet weights of stomach contents were measured to $0.01 \mathrm{mg}$ using a high precision balance, then prey in stomachs were identified in the laboratory under a stereomicroscope $(\times 10$ to 40$)$ to the lowest possible taxonomic level.
The following indices were calculated (see Hyslop 1980 for a review): (1) stomach fullness (stomach weight/shrimp weight $\times 100)$; (2) percentage numerical abundance of prey $(\% \mathrm{~N})$; and (3) percentage weight of prey $(\% \mathrm{~W})$.

When it was not possible to obtain a direct weight for each prey item, the weight of individual prey items consumed (WW, g) was estimated after the whole stomach content was weighed (0.1 $\mathrm{\mu g}$ precision) and after visual estimation of prey dominance in stomach contents under a stereomicroscope. Percentage volume of prey in stomach contents was estimated using a subjective points methods (Hellawell \& Abel 1971) for the different prey-species or prey-groups.

Concurrent with shrimp collection, benthopelagic macrofauna were sampled using a Macer-GIROQ suprabenthic sledge. In the 2 areas (Cabrera and Sóller, Fig. 1) samples were taken at 4 depths (150, 350,650 and $750 \mathrm{~m}$ ) every 2 mo spanning the 6 surveys between August 2003 and June 2004. During the same surveys, samples of zooplankton were collected using a WP2 at the same stations and depths (see details in Cartes et al. 2008). Both types gear were equipped with $0.5 \mathrm{~mm}$ mesh size nets and had similar mouth apertures (Macer-GIROQ: $0.8 \mathrm{~m}^{2}$; WP2: $1 \mathrm{~m}^{2}$ ). Suprabenthos and mesozooplankton were frozen on board $\left(-20^{\circ} \mathrm{C}\right)$, then samples were sorted in the laboratory and all the specimens identified to the lowest taxonomic level (except Copepoda: to suborder), counted and weighed.

For stable isotope analyses, muscle tissue samples (the abdomen without exoskeleton) were dissected out and dried to constant weight at $60^{\circ} \mathrm{C}$, then ground to a fine powder with a mortar and pestle. Plesionika martia specimens were analyzed from Cabrera and Sóller (3 specimens of about the same size for each survey per area; medium size $21.76 \pm 1.91 \mathrm{~mm}$ [SD] CL), while only $P$. heterocarpus specimens from Sóller were processed (3 specimens of about the same size for each month; medium size: $14.75 \pm 1.15 \mathrm{~mm}$ [SD] CL).

Using continuous flow, the samples were introduced into a Thermo Electron Flash EA 1112 elemental analyzer coupled to an isotope ratio mass spectrometer (SPM, Thermo Electron Delta Plus XP). Three capsules of an internal reference (internationally certified urea) were analysed at the beginning of each sequence and once every 6 samples to compensate for machine drift and as a quality control measure. Experimental precision (based on the SD of replicates of the internal standard) was $<0.2 \%$ for $\delta^{15} \mathrm{~N}$ and $<0.1 \%$ for $\delta^{13} \mathrm{C} . \delta^{13} \mathrm{C}$ and $\delta^{15} \mathrm{~N}$ values were obtained in parts per thousand (\%) relative to Vienna Pee Dee Belemnite (vPDB) and atmospheric $\mathrm{N}_{2}$ standards, respectively, according to the following formula: 


$$
\begin{gathered}
\text { where } \delta^{13} \mathrm{C} \text { or } \delta^{15} \mathrm{~N}=\left[\left(R_{\text {sample }} / R_{\text {standard }}\right)-1\right] \times 10^{3} \\
R={ }^{13} \mathrm{C} /{ }^{12} \mathrm{C} \text { or }{ }^{15} \mathrm{~N} /{ }^{14} \mathrm{~N}
\end{gathered}
$$

$\delta^{15} \mathrm{~N}$ values were converted to trophic level based on the assumption that there was a fractionation of $3.4 \%$ per trophic level (Post 2002) and that the base material (copepods) had a trophic level of 2:

$$
\mathrm{TL}=\left(\frac{\delta^{15} \mathrm{~N}_{\text {Ples }}-\delta^{15} \mathrm{~N}_{\text {ref }}}{3.4}\right)+2
$$

where TL is the trophic level of Plesionika species, $\delta^{15} \mathrm{~N}_{\text {Ples }}$ is the mean $\delta^{15} \mathrm{~N}$ of Plesionika, and $\delta^{15} \mathrm{~N}_{\text {ref }}$ is the mean $\delta^{15} \mathrm{~N}$ of copepods.

Data processing. General affinities between the samples (diets) were established using a non parametric multidimensional scaling analysis (nMDS) (Clarke \& Warwick 1994) after standardization and log-transformation of a data matrix based on prey weight for each haul. Analyses were performed separately for Plesionika martia and $P$. heterocarpus, and with both species together. Based on the null hypothesis that there were no differences between months or between areas (Cabrera and Sóller), a 2 factor PERMANOVA (Anderson 2001) (factor 1: area, fixed with 2 levels; factor 2 : month, random with 6 levels, nested in area) was created and performed on a Bray-Curtis resemblance matrix. Spearman's correlation coefficients were calculated for stomach fullness and the projections of diet per haul along MDS dimensions (DIM1, DIM2) both correlated with (1) sampling variables (time of sampling, depth, latitude, longitude, and month), (2) oceanographic/geochemical variables (temperature, salinity, percentage of organic matter in the sediment, redox potential, and chlorophyll a concentration collected at the time of sampling and at intervals of 4, 3, 2, and 1 mo before sampling, grain size and percentage of fine particles of sediment), (3) biological features of the shrimps [mean carapace length (CL), and weight (W) per haul, different stages of female maturity: stage 1 and 2 as discussed above; and 3 comprising stages 3 and 4 grouped together (ovigerous females)]. Data on surface chl a concentration were obtained from the Ocean Color Time-Series Online Visualization and Analysis System (available at: reason.gsfc.nasa.gov/Giovanni), which provides daily, weekly and monthly average values for surface temperature and phytoplankton pigment concentration (PP). All these were tested as possible explanatory variables of feeding (fullness) and dietary patterns deduced from MDS analysis. Correlations were also performed with the abundance of available resources in the environment, such as gelatinous plankton and euphausiids. Seasonal changes in suprabenthic and planktonic resources (abundance and biomass standardized data) were also estimated (Cartes et al. 2008) and compared with Plesionika diet.
A multiple linear regression model (MLR) relating dimensions 1 and 2 of the nMDS analysis to environmental (time of sampling, depth, latitude and longitude, oceanographic data and trophic variables) and biological variables (maturity state, density and mean CL) was established by forward stepwise multiple regression using the complete data set (Plesionika martia: 18 cases; Plesionika spp.: 33 cases). All MLR models were generated using the software Statistica 6.0 .

The abundance of mature females was also correlated with fullness and caloric content of prey (Madurell \& Cartes 2005, T. Madurell unpubl. data) in the stomachs throughout the sampling period. Oneway ANOVA was used to compare fullness among seasons (months); data were arc-sine transformed to remove dependency of variance on the mean (Underwood, 1997). The assumption of normality was tested using the Kolmogorov-Smirnov test, and Cochran's test was used to check the homogeneity of variances. When data were not normally distributed, the KruskallWallis $(\mathrm{K}-\mathrm{W})$ test was applied on the raw data. A post hoc Tukey HSD test (for unequal sample size) was applied to locate pairwise differences.

One-way ANOVAs were also used to study seasonal variations in mean $\delta^{15} \mathrm{~N}$ and $\delta^{13} \mathrm{C}$, comparing means among months, and a post hoc Tukey test was performed to test for pairwise differences.

\section{RESULTS}

\section{Depth distribution and abundance}

Plesionika heterocarpus was most abundant at $350 \mathrm{~m}$ throughout the year off Soller (Fig. 2b), while in Cabrera this species inhabited deeper bottoms from August to November and migrated to shallower depths $(250$ to $350 \mathrm{~m}$ ) from April to June (Fig. 2a). P. martia was more abundant between 580 and $660 \mathrm{~m}$ during all the sampled months, reaching maximum abundance in September and November in the 2 areas (Fig. 2c,d).

The size of Plesionika heterocarpus ranged from 6.3 to $18 \mathrm{~mm}$ (mean $\mathrm{CL}=14.5 \pm 1.7$ [SD]), that of $P$. martia from 14.2 to 26.2 (mean $C L=21.6 \pm 1.1$ ) (Appendix 1). The mean size of samples for the 2 species did not vary significantly between the months examined (ANOVA, $\mathrm{p}>0.05$ for P. martia and P. heterocarpus in Cabrera and Sóller).

\section{Diet composition and seasonal pattern}

Diet composition (Appendix 2, available as MEPS Supplementary Material at: www.int-res.com/articles/ 

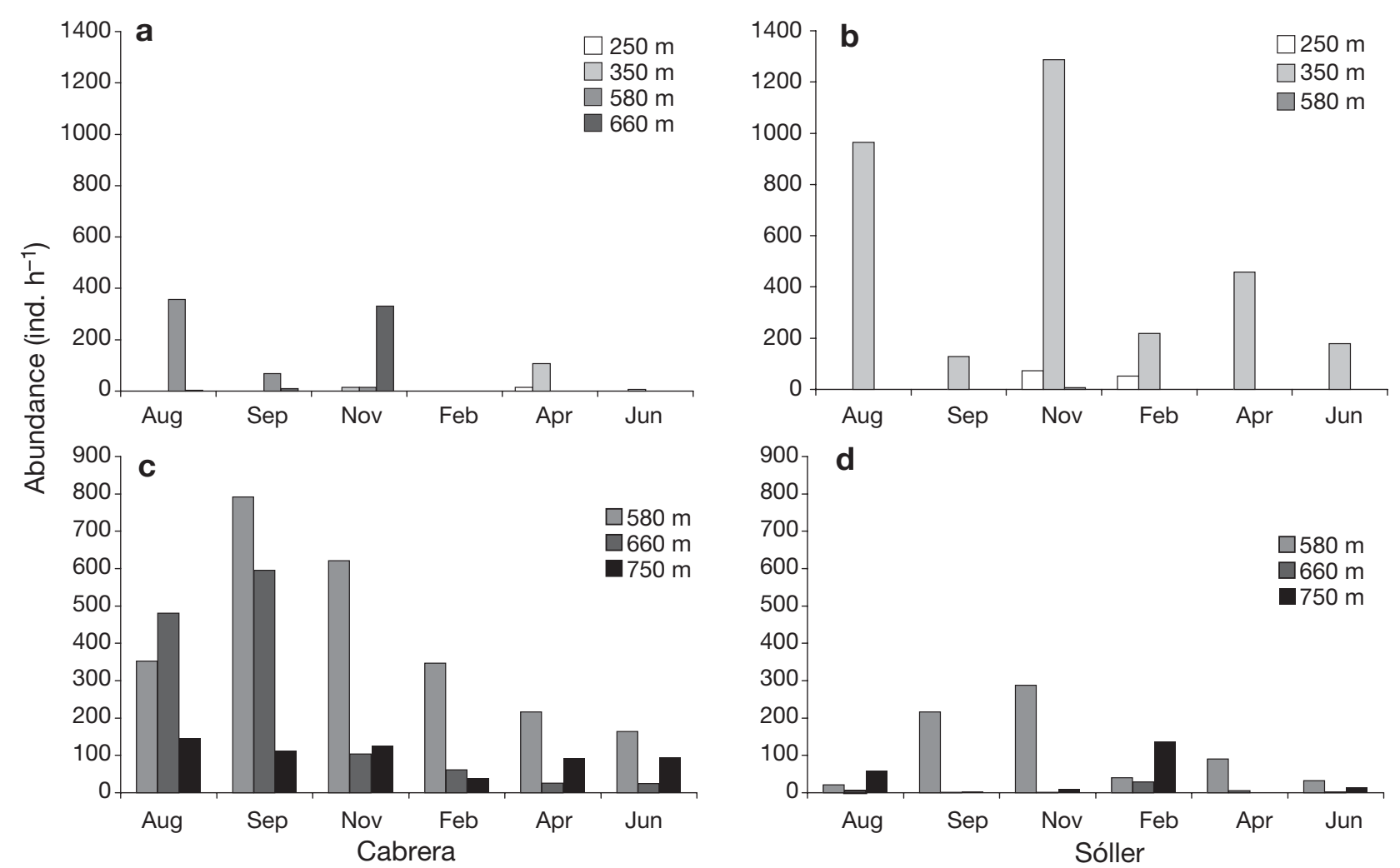

Fig. 2. Plesionika heterocarpus and P. martia. Abundance (ind. $\left.\mathrm{h}^{-1}\right)$ by month and depth of $(\mathrm{a}, \mathrm{b})$ P. heterocarpus and (c,d) P. martia off Cabrera and Sóller

suppl/m355p219_app.pdf) was examined by season, based on the seasonal groups revealed by nMDS analyses (see Fig. 4). The diet of Plesionika heterocarpus was highly diversified; a total of 78 different taxa were identified. Polychaetes, the decapod Pasiphaea sivado, euphausiids (Euphausia spp, Meganycthiphanes norvegica and Nycthiphanes couchii), hyperiids (mainly Phronima sp. and Scina spp.) and tanaids (mainly Apseudidae) were the principal food items. Benthic remains, i.e. ostracods, holothurian ossicles, echinoid tests and sponge spicules, were also abundant. Foraminiferans, both benthic and planktonic (i.e. Elphidium spp. and Globigerina spp, probably sedimented tecae), represented a very abundant category in the diet of P.heterocarpus, but these were probably ingested accidentally together with other benthic remains. Significant differences were found in mean prey weight (ANOVA $F_{1,244}=7.53, \mathrm{p}<10^{-6}$ ) and fullness (ANOVA $F_{1,244}=6.75, \mathrm{p}<10^{-6}$ ) by month.

The diet of Plesionika martia was as highly diversified as that of $P$. heterocarpus (Appendix 2); more than 90 taxa were identified in stomach contents. It preyed mostly on mesopelagic decapods (Pasiphaeidae and Sergestidae), euphausiids (Meganyctiphanes norvegica and Nematoscelis megalops), hyperiids (Phrosina semilunata, Phronima sedentaria and Vibilia armata), pelagic molluscs (Cymbulia peroni and Clyo piramidata), salps (Iasis zonaria) and mesopelagic fish (small Myctophidae and Stomiiformes, i.e. Cyclothone braueri). Mean prey weight (ANOVA $F_{1,535}=2.78, \mathrm{p}=$ $0.02)$ and fullness $(\mathrm{K}-\mathrm{W} \mathrm{p}=0.02)$ varied monthly. Overall nMDS for the 2 species showed a clear separation between $P$. heterocarpus and P. martia diets (Fig. 3) and showed a seasonal pattern for both species (Fig. 4a,b). Two seasonal groups were evident in $P$. heterocarpus diet (Fig. 4a); the first consisted of summer-autumn samples (from August to November) and the second comprised winter-spring samples (from February to June). Symmetrical PERMANOVA provided evidence for statistical differences between months (Table 1a). For P. martia, 3 groups were revealed by nMDS analysis (Fig. 4b), showing a different pattern from that of the shallow water $P$. heterocarpus: the first group comprised late summer samples from August and September, the second autumn-winter samples from November and February and the last contained spring-early summer samples from April and June. Samples from November and February appeared more dispersed than the other 2 groups. Symmetrical PERMANOVA showed significant differences in the diets between months (see Table 1b).

Seasonal changes in the main prey biomass were detected for the 2 species; these trends were very different for Cabrera and Sóller (Fig. 5). 


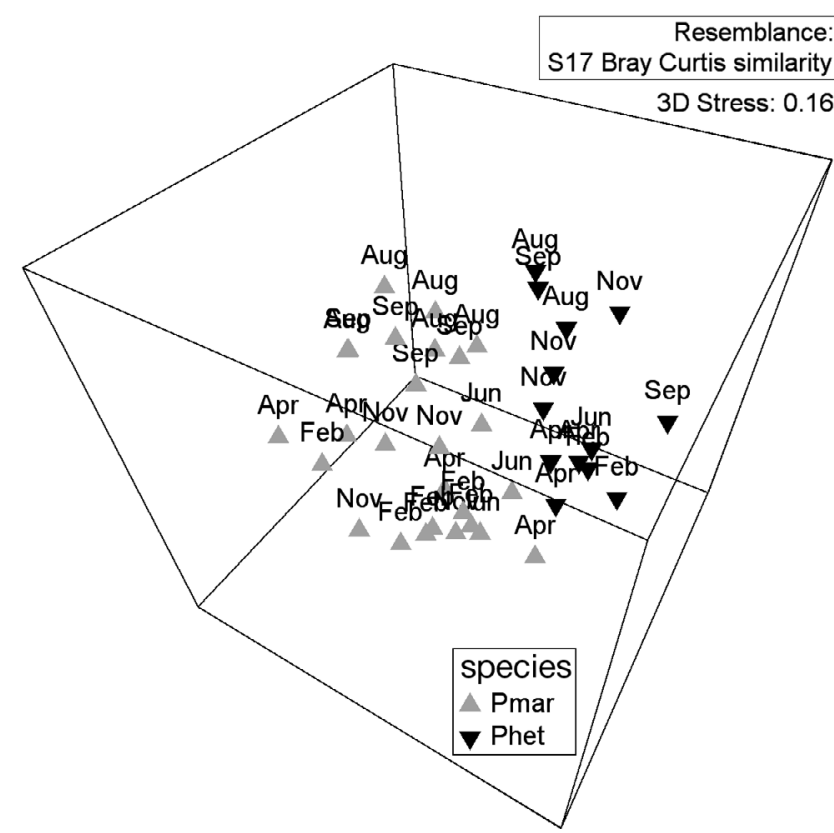

Fig. 3. Tridimensional nMDS ordination of foregut contents samples of Plesionika martia (Pmar) and P. heterocarpus (Phet) for the whole sampling period. Labels indicate sampling months

In summer-autumn, Plesionika heterocarpus off Cabrera preyed mainly on polychaetes, while in the second part of the year, it consumed mostly euphausiids and decapods (Fig. 5a). Off Sóller, the diet was dominated by decapods in September-November and by euphausiids in February-April (Fig. 5b). A temporal shift in the peak of euphausiids in stomach contents was detected in the 2 areas, with a peak in February off Sóller, and in April off Cabrera.

For Plesionika martia, a dominance of gelatinous plankton (mainly Salpidae) was observed in both Cabrera and Sóller in September (Fig. 5c,d). Off Cabrera, it preyed mainly on euphausiids in November and June, on decapods from February to April and on hyperiids in September. A different trend was detected off Sóller, with a dominance of hyperiids in August, euphausiids and mesopelagic fish in April.

Correlations with the projections of samples in MDS dimensions 1 and 2 ( $\mathrm{n}=$ 23) showed that in Plesionika heterocarpus dimension 1 was not correlated with any of the variables examined, while dimension 2 was significantly correlated (Spearman correlation) with mean salinity, area and surface chl a concentration recorded 4, 3 and 2 mo before sampling (Table 2a). Fullness was also correlated with depth and mean grain size; density
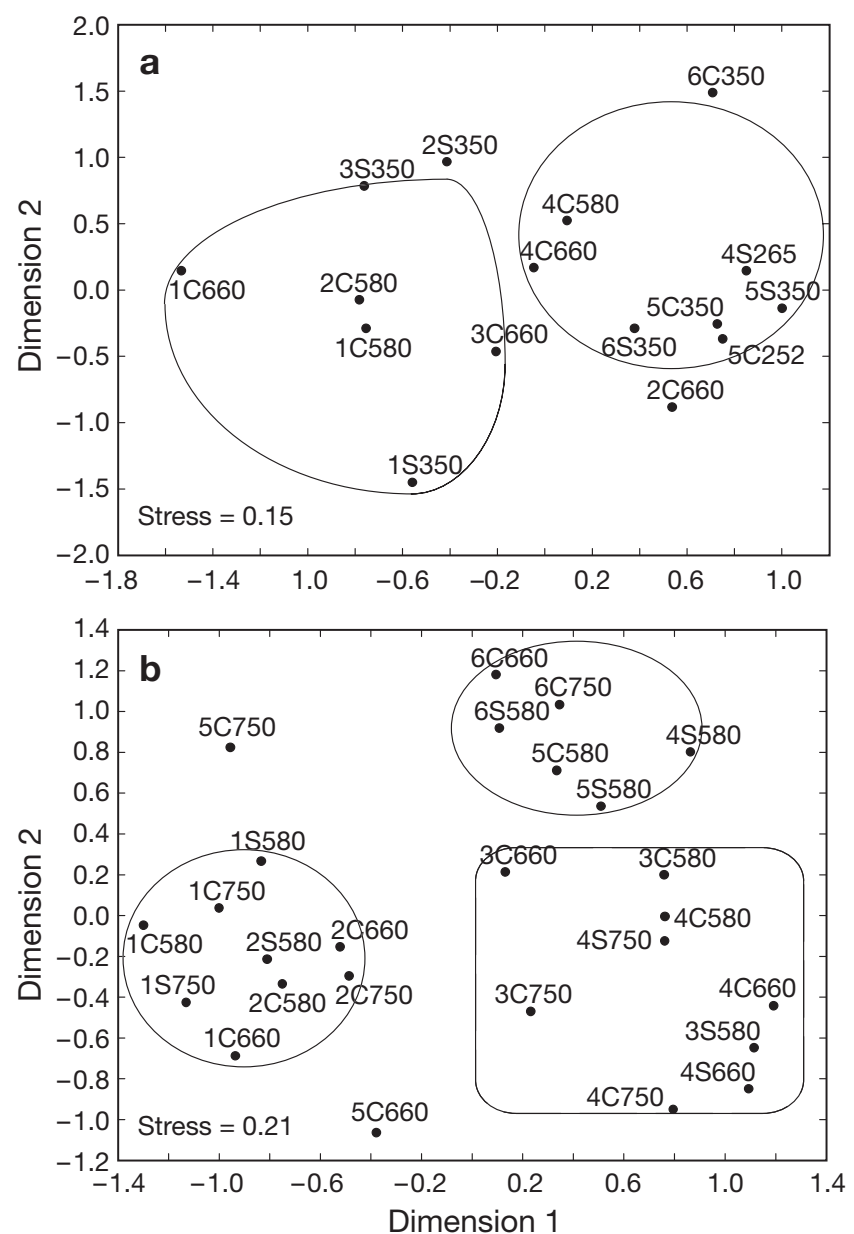

Fig. 4. Multidimensional scaling ordination of foregut contents samples for (a) Plesionika heterocarpus and (b) P. martia. Labels indicate sampling months, area and depth (in number) as follows: $1=$ August $; 2=$ September; $3=$ November; $4=$ February; $5=$ April and $6=$ June; $\mathrm{C}=$ Cabrera; $\mathrm{S}=$ Sóller

of mature females was correlated with area. In addition, a significant correlation was found between fullness and location of hauls and a number of biological features such as state of maturity (Table 2b). For $P$.

Table 1. PERMANOVA based on the Bray-Curtis dissimilarities of standardized and log-transformed data for Plesionika heterocarpus (39 items, i.e. prey considered for analysis) and P. martia (52 items)

\begin{tabular}{|lrcccc|}
\hline Source & df & MS & $F$ & $p$ & Permutations \\
\hline P. heterocarpus & & & & & \\
Area & 1 & 1981.7 & 0.606 & 0.873 & 995 \\
Month(area) & 9 & 3343.1 & 3.141 & 0.001 & 995 \\
$\begin{array}{l}\text { Residual } \\
\text { Total }\end{array}$ & 2 & 1064.4 & & & \\
P. martia & 12 & & & & \\
Area & 1 & 3122 & 0.806 & 0.6759 & 9913 \\
Month(area) & 10 & 4304 & 2.090 & 0.0001 & 9789 \\
$\begin{array}{l}\text { Residual } \\
\text { Total }\end{array}$ & 14 & 2058.8 & & & \\
\hline
\end{tabular}




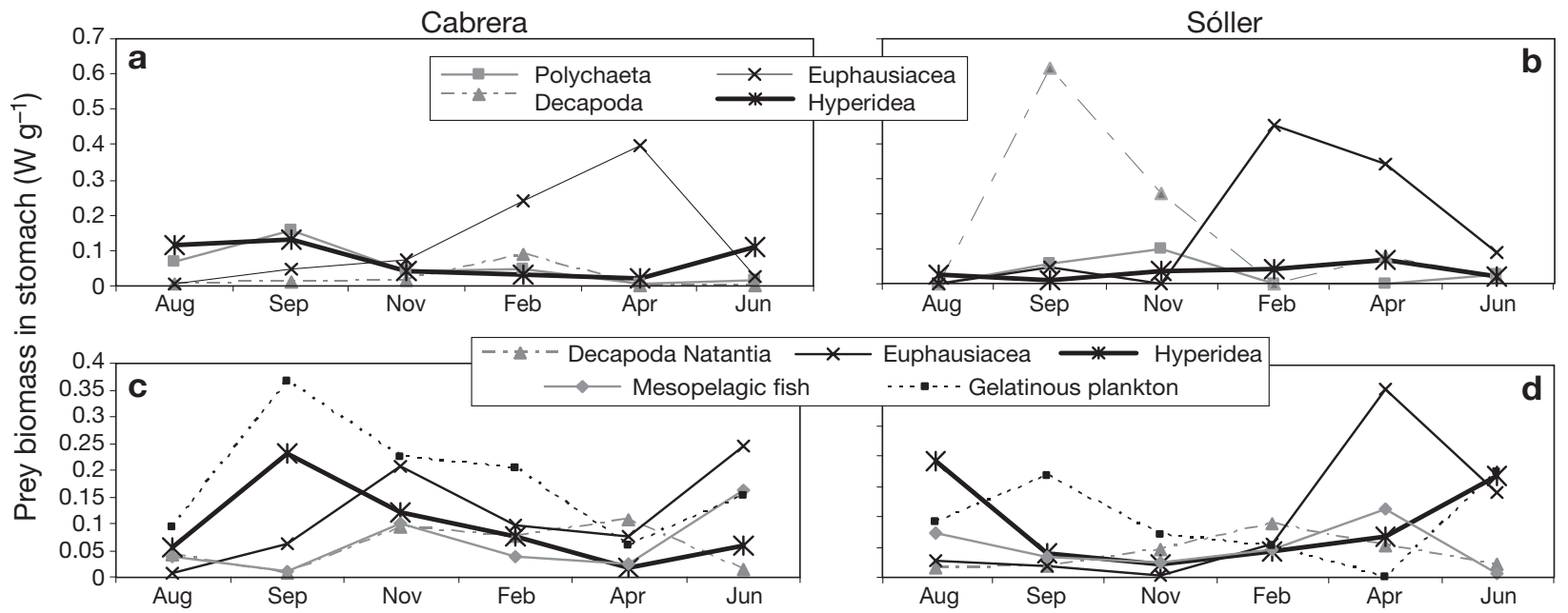

Fig. 5. Seasonal variation of dominant prey biomass $\left(\mathrm{W} \mathrm{g}^{-1}\right)$ in stomach contents of $(\mathrm{a}, \mathrm{b})$ Plesionika heterocarpus and (c,d) P. martia by month off $(\mathrm{a}, \mathrm{c})$ Cabrera and $(\mathrm{b}, \mathrm{d})$ Sóller

Table 2. Spearman correlation results for (a) fullness and MDS dimension 2 (DIM2) versus geographical, chemico-physical and biological variables ( $\mathrm{n}=21$ hauls) and (b) fullness versus biological and geographical parameters for all Plesionika heterocarpus (Phet) specimens ( $\mathrm{n}=237$ full gut contents). Significant $(\mathrm{p}<0.05)$ correlations are in bold. Valid: no. of cases computed by program; $\mathrm{mV}$ (sup) and $\mathrm{mV}(5 \mathrm{~cm}$ ) are Redox recorded on surface and $5 \mathrm{~cm}$ below surface of sediment sample (in $\mathrm{mV}$ ), respectively.

For other abbreviations see Table 3

\begin{tabular}{|c|c|c|c|c|c|c|c|c|}
\hline \multirow[t]{2}{*}{ a } & \multicolumn{4}{|c|}{ - Fullness } & \multirow[b]{2}{*}{ Valid } & \multicolumn{2}{|c|}{ - DIM2 } & \multirow[b]{2}{*}{$\mathrm{p}$} \\
\hline & Valid & Spearman $\mathrm{r}$ & $t(N-2)$ & $\mathrm{p}$ & & Spearman $\mathrm{r}$ & $t(N-2)$ & \\
\hline Month & 11 & 0.487 & 1.675 & 0.128 & 21 & -0.035 & -0.151 & 0.881 \\
\hline Area & 11 & 0.173 & 0.528 & 0.611 & 21 & -0.481 & -2.390 & 0.027 \\
\hline Siphonophora & 11 & -0.191 & -0.583 & 0.574 & 15 & -0.041 & -0.148 & 0.884 \\
\hline Thaliacea & 11 & 0.337 & 1.074 & 0.311 & 15 & 0.174 & 0.636 & 0.536 \\
\hline Euphausiacea & 11 & -0.091 & -0.274 & 0.790 & 15 & 0.478 & 1.964 & 0.071 \\
\hline Depth & 11 & -0.890 & -5.869 & 0.000 & 15 & -0.104 & -0.376 & 0.713 \\
\hline $\mathrm{T}^{\circ} \mathrm{C}$ mean & 11 & 0.352 & 1.127 & 0.289 & 15 & -0.373 & -1.448 & 0.171 \\
\hline $\mathrm{S}$ (mean salinity) & 11 & -0.227 & -0.700 & 0.502 & 15 & 0.621 & 2.857 & 0.013 \\
\hline Fluorescence & 4 & -0.400 & -0.617 & 0.600 & 4 & -0.800 & -1.886 & 0.200 \\
\hline $\mathrm{T}_{5 \mathrm{mab}}$ & 11 & 0.209 & 0.641 & 0.537 & 15 & -0.358 & -1.383 & 0.190 \\
\hline $\mathrm{S}_{5 \mathrm{mab}}$ & 11 & -0.073 & -0.219 & 0.832 & 15 & 0.247 & 0.918 & 0.376 \\
\hline$\%$ OM & 8 & -0.262 & -0.665 & 0.531 & 13 & -0.521 & -2.023 & 0.068 \\
\hline Mud (\% in sediment) & 8 & -0.381 & -1.009 & 0.352 & 13 & -0.328 & -1.151 & 0.274 \\
\hline Mean grain size & 8 & 0.738 & 2.680 & 0.037 & 13 & -0.449 & -1.667 & 0.124 \\
\hline mV (sup) & 9 & 0.000 & 0.000 & 1.000 & 11 & 0.187 & 0.572 & 0.581 \\
\hline $\mathrm{mV}(5 \mathrm{~cm})$ & 9 & 0.233 & 0.635 & 0.546 & 11 & 0.187 & 0.572 & 0.581 \\
\hline $\mathrm{Chl} a_{4 \mathrm{mo}}$ & 11 & 0.255 & 0.790 & 0.450 & 15 & -0.649 & -3.079 & 0.009 \\
\hline Chl $a_{3 \mathrm{mo}}$ & 11 & 0.428 & 1.422 & 0.189 & 15 & -0.592 & -2.649 & 0.020 \\
\hline $\mathrm{Chl} a_{2 \mathrm{mo}}$ & 11 & 0.493 & 1.701 & 0.123 & 15 & -0.571 & -2.509 & 0.026 \\
\hline Chl $a_{1 \mathrm{mo}}$ & 11 & 0.451 & 1.516 & 0.164 & 15 & -0.284 & -1.070 & 0.304 \\
\hline Chl $a_{\text {sim }}$ & 11 & 0.489 & 1.680 & 0.127 & 15 & -0.134 & -0.489 & 0.633 \\
\hline Shrimp density (Phet) & 11 & 0.118 & 0.357 & 0.729 & 6 & 0.600 & 1.500 & 0.208 \\
\hline Mean CL (Phet) & 11 & -0.382 & -1.239 & 0.247 & 6 & 0.257 & 0.532 & 0.623 \\
\hline Density mature females (Phet) & 11 & 0.100 & 0.302 & 0.770 & 6 & 0.486 & 1.111 & 0.329 \\
\hline \multirow[t]{2}{*}{ b } & \multicolumn{4}{|c|}{ Fullness } & & & & \\
\hline & Valid & Spearman $r$ & $t(N-2)$ & $\mathrm{p}$ & & & & \\
\hline Haul & 237 & 0.150 & 2.319 & 0.021 & & & & \\
\hline CL & 237 & -0.092 & -1.414 & 0.159 & & & & \\
\hline $\operatorname{sex}$ & 237 & -0.099 & -1.531 & 0.127 & & & & \\
\hline W (wet weight) & 237 & -0.093 & -1.424 & 0.156 & & & & \\
\hline$\%$ r (\% stomach replenishment) & 237 & 0.896 & 30.912 & 0.000 & & & & \\
\hline Maturity & 233 & -0.145 & -2.234 & 0.026 & & & & \\
\hline Latitude & 237 & -0.043 & -0.660 & 0.510 & & & & \\
\hline Longitude & 237 & -0.066 & -1.017 & 0.310 & & & & \\
\hline Depth & 237 & -0.150 & -2.332 & 0.021 & & & & \\
\hline Hour_beg & 237 & 0.244 & 3.855 & 0.000 & & & & \\
\hline Hour_end & 237 & 0.245 & 3.880 & 0.000 & & & & \\
\hline Month & 237 & -0.024 & -0.364 & 0.716 & & & & \\
\hline
\end{tabular}


Table 3. Spearman correlation results for (a) MDS dimensions 1 and 2 (DIM1, DIM2) and fullness versus biological and geographical parameters of all Plesionika martia (Pmar) specimens ( $\mathrm{n}=516$ full stomachs) and (b) fullness of $P$. martia samples from Sóller $(n=6)$ versus geographical, chemico-physical and biological variables and resource availability. Significant correlations $(\mathrm{p}<0.05)$ are in bold

\begin{tabular}{|c|c|c|c|c|c|c|c|c|c|c|c|c|}
\hline \multirow{2}{*}{ a } & \multicolumn{4}{|c|}{$\longrightarrow$ DIM1 } & \multicolumn{4}{|c|}{$\longrightarrow$ DIM2 } & \multicolumn{4}{|c|}{$\longrightarrow$ Fullness } \\
\hline & Valid & Spearman $r$ & $t(N-2)$ & $\mathrm{p}$ & Valid & Spearman $\mathrm{r}$ & $\mathrm{t}(\mathrm{N}-2)$ & $\mathrm{p}$ & Valid & Spearman $r$ & $t(N-2)$ & $\mathrm{p}$ \\
\hline Fullness & 500 & 0.176 & 3.993 & 0.000 & 500 & 0.087 & 1.947 & 0.052 & & & & \\
\hline Haul & 500 & 0.223 & 5.094 & 0.000 & 500 & 0.100 & 2.242 & 0.025 & 516 & 0.043 & 0.985 & 0.325 \\
\hline CL & 500 & -0.150 & -3.391 & 0.001 & 500 & 0.004 & 0.097 & 0.923 & 516 & -0.068 & -1.534 & 0.126 \\
\hline Sex & 500 & -0.472 & -11.958 & 0.000 & 500 & 0.226 & 5.176 & 0.000 & 516 & 0.001 & 0.014 & 0.989 \\
\hline W & 500 & -0.147 & -3.322 & 0.001 & 500 & 0.051 & 1.131 & 0.259 & 516 & 0.010 & 0.227 & 0.821 \\
\hline$\% \mathrm{r}$ & 500 & 0.158 & 3.565 & 0.000 & 500 & 0.057 & 1.277 & 0.202 & 516 & 0.955 & 72.744 & 0.000 \\
\hline Maturity & 499 & -0.398 & -9.663 & 0.000 & 499 & -0.067 & -1.502 & 0.134 & 515 & -0.173 & -3.978 & 0.000 \\
\hline Latitude & 500 & 0.129 & 2.910 & 0.004 & 500 & 0.162 & 3.671 & 0.000 & 516 & 0.106 & 2.412 & 0.016 \\
\hline Longitude & 500 & -0.165 & -3.745 & 0.000 & 500 & -0.063 & -1.415 & 0.158 & 516 & -0.073 & -1.661 & 0.097 \\
\hline Depth & 500 & -0.136 & -3.063 & 0.002 & 500 & -0.042 & -0.930 & 0.353 & 516 & -0.040 & -0.914 & 0.361 \\
\hline Month & 500 & 0.652 & 19.197 & 0.000 & 500 & 0.384 & 9.287 & 0.000 & 516 & 0.137 & 3.129 & 0.002 \\
\hline Hour_beg & 500 & 0.215 & 4.921 & 0.000 & 500 & 0.131 & 2.952 & 0.003 & 516 & 0.040 & 0.918 & 0.359 \\
\hline Hour_end & 500 & 0.225 & 5.162 & 0.000 & 500 & 0.141 & 3.167 & 0.002 & 516 & 0.048 & 1.090 & 0.276 \\
\hline DIM1 & & & & & & & & & 500 & 0.176 & 3.993 & 0.000 \\
\hline DIM2 & & & & & & & & & 500 & 0.087 & 1.947 & 0.052 \\
\hline \multirow{2}{*}{\multicolumn{9}{|c|}{ b }} & \multirow{2}{*}{\multicolumn{4}{|c|}{$\begin{array}{ll}\text { Fullness } & \\
\text { Valid Spearman } r \text { t(N-2) } \quad p\end{array}$}} \\
\hline & & & & & & & & & & & & \\
\hline \multicolumn{9}{|c|}{ Month } & 6 & -0.265 & -0.549 & 0.612 \\
\hline \multicolumn{9}{|c|}{ Siphonophora } & 5 & -0.900 & -3.576 & 0.037 \\
\hline \multicolumn{9}{|c|}{ Thaliacea } & 5 & -0.447 & -0.866 & 0.450 \\
\hline \multicolumn{9}{|c|}{ Euphausiacea } & 6 & -0.143 & -0.289 & 0.787 \\
\hline \multicolumn{9}{|c|}{ Depth } & 5 & -0.900 & -3.576 & 0.037 \\
\hline \multicolumn{9}{|c|}{$\mathrm{T}^{\circ} \mathrm{C}$ mean } & 6 & 0.000 & 0.000 & 1.000 \\
\hline \multicolumn{9}{|c|}{ S (mean salinity) } & 6 & -0.029 & -0.057 & 0.957 \\
\hline \multicolumn{9}{|c|}{$\mathrm{T}_{5 \mathrm{mab}}=$ temperature recorded at $5 \mathrm{~m}$ above the bottom } & 6 & 0.829 & 2.960 & 0.042 \\
\hline \multicolumn{9}{|c|}{$\mathrm{S}_{5 \mathrm{mab}}=$ salinity recorded at $5 \mathrm{~m}$ above the bottom } & 6 & 0.257 & 0.532 & 0.623 \\
\hline \multicolumn{9}{|c|}{$\% \mathrm{OM}=$ percentage of organic matter in the sediment } & 4 & -0.800 & -1.886 & 0.200 \\
\hline \multicolumn{9}{|c|}{ Chl $a_{4 \mathrm{mo}}=$ chl a concentration on the surface recorded 4 mo before the sampling } & 6 & 0.029 & 0.057 & 0.957 \\
\hline \multicolumn{9}{|c|}{ Chl $a_{3 \mathrm{mo}}=\mathrm{chl} a$ concentration on the surface recorded 3 mo before the sampling } & 6 & 0.029 & 0.057 & 0.957 \\
\hline \multicolumn{9}{|c|}{ Chl $a_{2 \mathrm{mo}}=$ chl $a$ concentration on the surface recorded 2 mo before the sampling } & 6 & 0.200 & 0.408 & 0.704 \\
\hline \multicolumn{9}{|c|}{ Chl $a_{1 \mathrm{mo}}=\mathrm{chl}$ a concentration on the surface recorded $1 \mathrm{mo}$ before the sampling } & 6 & -0.058 & -0.116 & 0.913 \\
\hline \multicolumn{9}{|c|}{ Chl $a_{\text {sim }}=$ chl $a$ concentration on the surface recorded simultaneously with sampling } & 6 & -0.086 & -0.172 & 0.872 \\
\hline \multicolumn{9}{|c|}{ Shrimp density $(\mathrm{Pmar})=$ total density of shrimps collected in each haul } & 6 & 0.829 & 2.960 & 0.042 \\
\hline \multicolumn{9}{|c|}{ Mean CL $($ Pmar $)=$ mean carapace length $(\mathrm{mm})$ of shrimps collected in each haul } & 6 & -0.771 & -2.425 & 0.072 \\
\hline \multicolumn{9}{|c|}{$\begin{array}{l}\text { Density of mature females (Pmar) }=\text { total density of females stage } 3-4 \\
\text { (including ovigerous females) collected in each haul }\end{array}$} & 6 & 0.486 & 1.111 & 0.329 \\
\hline
\end{tabular}

martia, there was a significant correlation between the projection of hauls in dimension 1 and (1) all the geographical and biological variables, (2) month, (3) depth and time of sampling, (4) fullness, (5) sex and (6) state of maturity (Table 3a). Correlations (2) and (3) are among the most remarkable in ecological terms. Among the chemico-physical variables, a significant correlation was found between MDS dimension 1 and the percentage of organic matter in sediment $(r=-0.44, p=0.02)$. MDS dimension 2 was correlated with haul, latitude, month, time of sampling (beginning and end) and sex (Table 3a). Fullness of $P$. martia was also correlated with state of maturity $\left(\mathrm{r}=-0.17 ; \mathrm{p}<10^{-4}\right)$; it was also linked to latitude $(\mathrm{r}=0.11 ; \mathrm{p}=0.01)$ and month $(\mathrm{r}=0.13 ; \mathrm{p}=$
0.001), but was not correlated with any of the environmental variables examined, although density of mature females was significantly correlated with month ( $\mathrm{r}=-0.63 ; \mathrm{p}=0.005)$, pigment concentration recorded at time of sampling $(\mathrm{r}:-0.56 ; \mathrm{p}=0.01)$ and one month before $\left(\mathrm{r}=-0.58 ; \mathrm{p}<10^{-3}\right)$. When Cabrera and Sóller were treated separately in consideration of their different oceanographic features and the strongly pelagic diet of $P$. martia, fullness in Sóller was significantly correlated with abundance of gelatinous plankton (i.e. Siphonophora $r=-3.57, p=0.037$ ), depth $(\mathrm{r}=-3.57, \mathrm{p}=0.037)$, temperature $(\mathrm{r}=2.96 ; \mathrm{p}=$ $0.04)$ and density of $P$. martia specimens $(\mathrm{r}=2.96 ; \mathrm{p}=$ 0.04) (Table 3b). Off Cabrera, fullness was not correlated with any of the variables examined. 
Table 4. Characteristics of the multiple linear regression (MLR) models constructed to predict MDS dimensions 1 (DIM1) and 2 (DIM2) for Plesionika martiaModels (1) and (2) — and to predict density for Plesionika spp.—Model (3). Chl a concentration recorded simultaneously with sampling (Chl $\left.a_{\text {sim }}\right)$ and 4 mo before sampling $\left(\mathrm{Chl} \mathrm{a}_{4 \mathrm{mo}}\right)$. Fullness and temperature recorded at $5 \mathrm{~m}$ above the bottom $\left(\mathrm{T}_{5 \mathrm{mab}}\right)$ are the independent variables

\begin{tabular}{lcccc}
\hline Model & $\mathrm{n}$ & $\mathrm{r}^{2}$ & $\mathrm{p}$ \\
\hline (1) $\log$ DIM1 $=-0.272+4.42 \log \mathrm{Chl} a_{\text {sim }}+1.01 \log$ fullness & 15 & 0.803 & $<10^{-5}$ \\
(2) $\log$ DIM2 $=0.23+3.25 \log \mathrm{Chl} a_{4 \mathrm{mo}}-2.94 \log \mathrm{Chl} a_{\text {sim }}$ & 18 & 0.674 & $<10^{-4}$ \\
(3) $\log$ density $=-59.72+4.74 \log \mathrm{T}_{5 \mathrm{mab}}$ & 33 & 0.608 & $<10^{-4}$ \\
\hline
\end{tabular}

Two MLR fullness models were obtained for Plesionika martia diet (Table 4). In model MLR1 (1), dimension 1 was significantly correlated with chl a concentration measured at the time of sampling $\left(\mathrm{Chl} a_{\text {sim }}\right)$ and with fullness. The fitted equation (Table 4) showed that this model explains $71.5 \%$ of the variability of dimension 1 values. In model MLR2 (2), dimension 2 was significantly correlated with $\mathrm{Chl} a_{4 \mathrm{mo}}$ and $\mathrm{Chl} a_{\text {sim }}$ but the goodness-of-fit was lower $\left(\mathrm{r}^{2}=0.356\right)$. The tolerance, which indicates the existing correlation between pairs of independent variables, was 0.972 in MLR1, and 0.899 in MLR2.

\section{Energy requirements and reproduction}

For the shallower species (Plesionika heterocarpus), which reproduces throughout the year, no clear trend was detected when comparing the abundance of mature females throughout the year and the caloric content of

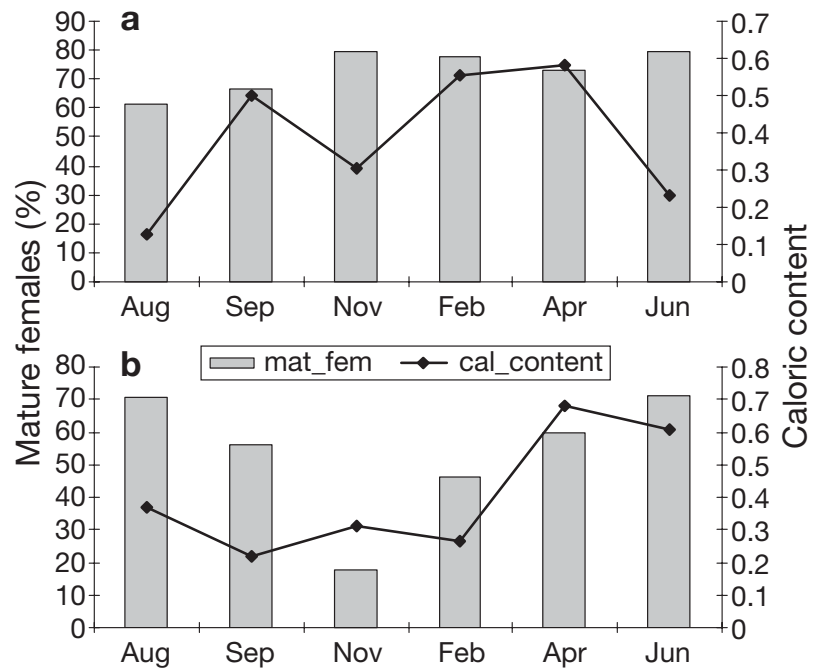

Fig. 6. Plesionika heterocarpus and P. martia. Monthly relationship between percentage of mature females (mat_fem) (Stages 2 to 4 ) and caloric content (cal_content, J mgDW ${ }^{-1}$ ) of prey in the stomach contents of (a) $P$. heterocarpus and (b) P. martia prey in the diet (Fig. 6a); 2 peaks in energy contents were observed, one in September and the other from February to June, both before the peaks in mature female abundance in November and June, respectively. In contrast, for $P$. martia, which has a reproductive peak during springsummer (Fig. 6b), there was an increase in energy requirements from February to April, before it reached the peak of the spawning period.

\section{Stable isotope analysis}

Significant seasonal changes were observed in $\delta^{13} \mathrm{C}$ values for Plesionika heterocarpus (mean $\delta^{13} \mathrm{C}=$ $-17.44 \% \pm 0.15$ [SD]) off Sóller (ANOVA $F_{1,19}=4.31$, $\mathrm{p}<0.05)$, although a post hoc test indicated that the source of variation (November differed from June) was not between adjacent months (Fig. 7b). No significant changes occurred in $\delta^{15} \mathrm{~N}$ by month; the mean value was $7.87 \%$ o $( \pm 0.17$ [SD]). The mean TL (trophic level), assuming copepods as a baseline (mean $\delta^{15} \mathrm{~N}$ values in Sóller $=5.25 \%$ ), was 2.77 .

A marked seasonal trend was observed for Plesionika martia; there was an abrupt enrichment in $\delta^{13} \mathrm{C}$
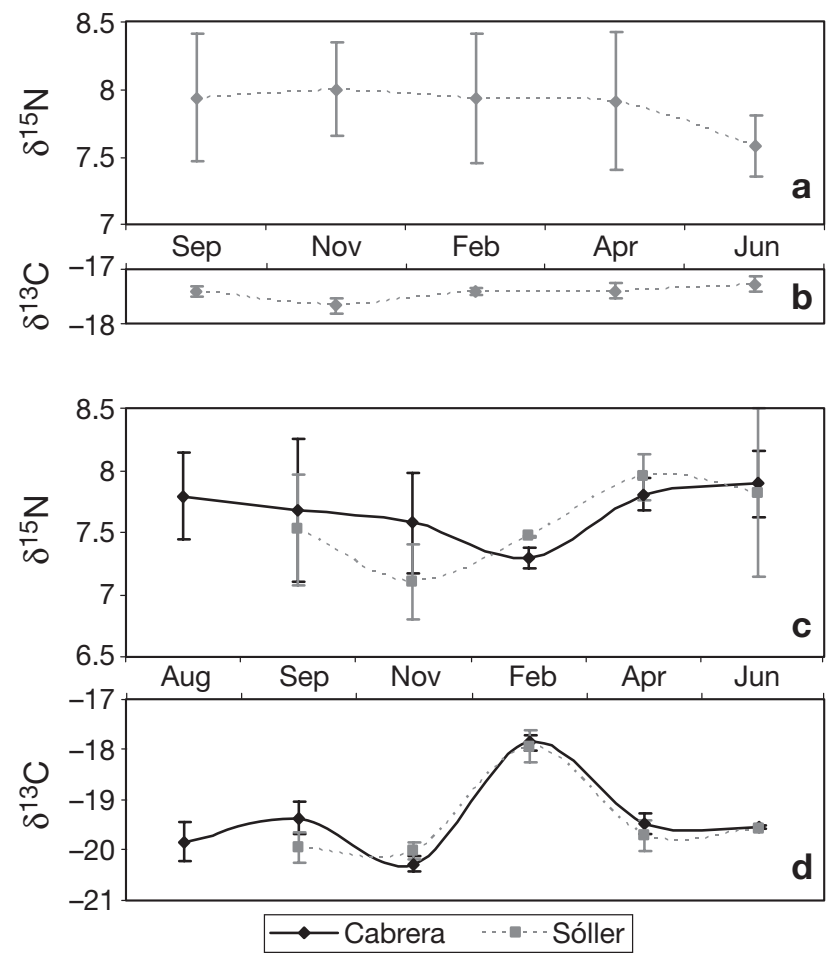

Fig. 7. Monthly values of $(\mathrm{a}, \mathrm{c}) \delta^{15} \mathrm{~N}$ and $(\mathrm{b}, \mathrm{d}) \delta^{13} \mathrm{C}$ for $(\mathrm{a}, \mathrm{b})$ Plesionika heterocarpus and $(\mathrm{c}, \mathrm{d}) P$. martia. Means $\pm \mathrm{SD}$ are shown 
value in February samples $\left(\delta^{13} \mathrm{C}=-17.9 \%\right.$ off both Cabrera and Sóller (Fig. 7d). Temporal differences were significant $\left(F_{1,32}=311.7, \mathrm{p}<10^{-3}\right.$ for Cabrera and $F_{1,16}=132.49, \mathrm{p}<10^{-5}$ for Sóller). Similarly, $\delta^{15} \mathrm{~N}$ values differed markedly between months in both Cabrera $\left(F_{1,32}=4.16, \mathrm{p}<0.05\right)$ and Sóller $\left(F_{1,16}=4.74, \mathrm{p}<0.05\right)$ (Fig. $7 \mathrm{C}$ ); the most depleted $\delta^{15} \mathrm{~N}$ value occurred in Cabrera in February, and in November in Sóller. The mean TL values of $P$. martia off Cabrera $\left(\delta^{15} \mathrm{~N}\right.$ of copepods $=4.54 \%$ ) and Sóller were 2.92 and 2.68 , respectively.

\section{DISCUSSION}

The diet of Plesionika species is based mainly on pelagic resources caught in the Benthic Boundary Layer located a few meters above the bottom (Angel 1990). They can be assigned to the trophic guild of 'non-migratory macroplankton feeders' proposed by Cartes et al. (2002).

Plesionika martia dwelling on the middle-slope (below ca. 350 m) (Abelló et al. 1988, Cartes et al. 1994) clearly fits within this guild. P. martia in the Balearic basin, as well as in the Catalan (Cartes 1993) and Alboran Seas (Fanelli \& Cartes 2004), preys mostly on mesopelagic decapods, euphausiids, hyperiids, salps, pelagic molluscs and mesopelagic fish.

As observed in previous studies (Labropoulou \& Kostikas 1999, Fanelli \& Cartes 2004), the contribution of benthic prey to the diet of the shallow water species Plesionika heterocarpus is important, although in the Balearic basin, mesopelagic resources (euphausiids and hyperiids) are more abundant in the diet than in other areas (Lagardére 1977, Sánchez et al. 2006). Off the Balearic archipelago, $P$. heterocarpus also preyed on benthic items such as polychaetes and tanaids; benthic remains (i.e. foraminiferans, ostracods, gastropods and bivalves) were often present in stomach contents.

The overall seasonal changes observed in the relative importance of preferred prey appeared related to fluctuations in available prey in the environment, as observed by the coupling of suprabenthos and zooplankton data (Cartes et al. 2008) with stomach content results, and as suggested in several studies of deep-sea fish (e.g. Gordon 1979, Blaber \& Bulman 1987).

The large amount of gelatinous plankton in Plesionika heterocarpus' diet in February off Sóller fit perfectly with gelatinous availability (Fig. 8a); in June off Cabrera, there was a clear relationship between the abundance of gelatinous material in the environment and in stomach contents. The abundance of other main prey (i.e. euphausiids and decapods) was not easily correlated with resource availability in the environment. Larger euphausiids and decapods such as Mega- nycthiphanes norvegica and Pasiphea spp., which were the main prey for these 2 taxa, are mesopelagic species barely collected by a sledge or zooplankton net with a $500 \mu \mathrm{m}$ mesh size (because of their size and great swimming ability, Cartes et al. 1994). Interestingly, mean size of euphausiids in the environment was related to the diet data; in April off Cabrera at about $350 \mathrm{~m}$, there was a peak of euphausiids (mainly Nycthiphanes couchii) in the diet, corresponding to a peak of $1.5 \mathrm{~mm} \mathrm{CL}$ euphausiids (Fig. 8e), indicating the presence of smaller species (such as $N$. couchi) with less swimming capability than the larger $M$. norvegica.

Gelatinous plankton was very abundant in the diet of Plesionika martia off both Cabrera and Sóller from September to February and also in June. This pattern fitted perfectly with gelatinous plankton abundance in the environment (Fig. 8b). It has often been observed that areas with dense salp aggregations have a particular scarcity of other zooplankton (Wormuth 1994) and this may explain the high biomass in the stomachs in the first part of the year. Moreover, the fullness index off Cabrera was high in September and November, probably due to the great abundance of this taxon in stomach contents. Gelatinous zooplankton has a low energy density, so more must be eaten to provide an adequate caloric intake. Fish and crustaceans of zooplankton typically have a 70 to $80 \%$ water content, while gelatinous zooplankton has a water content of 95\% (Davis 1993). A rough calculation shows that $15 \times$ the volume of gelatinous zooplankton must be ingested to yield the energy equivalent of non-gelatinous zooplankton (Welch 1997). In addition, gelatinous plankton in both the diet and the environment mainly comprised Siphonophora (i.e. Chelophyes appendiculata) and Thaliaceans (i.e. salps, mainly Iasis zonaria). The tunica of salps contains tunicine, a protein-polysaccaride complex (in which carbohydrates are associated with a collagen-like substance and elastin proteins) which makes these animals difficult to digest and possibly overestimated; this is also the case for some deep-sea sharks such as Galeus melastomus and G. atlanticus (E. Fanelli unpubl. data). Seasonal changes in the presence of salps may also reflect changes in currents (Arai 2005). Moreover, several hyperiids are often associated with gelatinous plankton, i.e. Phronima sedentaria (Keisuke 2004). We also found a simultaneous high abundance of gelatinous plankton and hyperiids in stomach contents (Fig. 5c,d).

Euphausiid abundance in the diet also showed a seasonal trend; peaks were detected in November and June in Plesionika martia specimens off Cabrera (Fig. 5c). This was correlated with the abundance of euphausiids in the environment (Fig. 8d). Maximum abundance in stomach contents off Sóller in April was not correlated with biomass in the environment but 

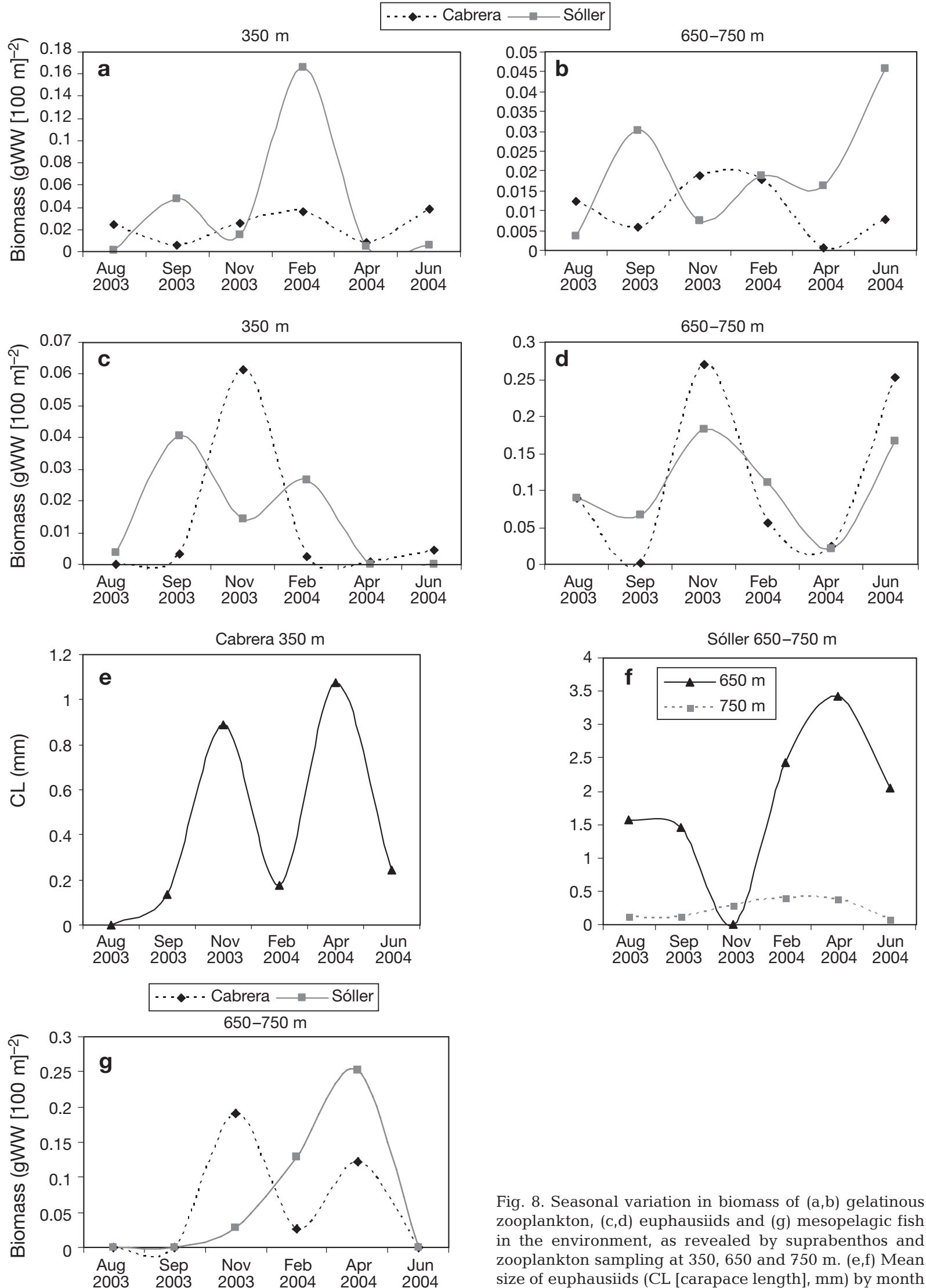

Fig. 8. Seasonal variation in biomass of $(a, b)$ gelatinous zooplankton, $(\mathrm{c}, \mathrm{d})$ euphausiids and $(\mathrm{g})$ mesopelagic fish in the environment, as revealed by suprabenthos and zooplankton sampling at 350,650 and $750 \mathrm{~m}$. (e,f) Mean size of euphausiids (CL [carapace length], $\mathrm{mm}$ ) by month 
rather with euphausiid size in the suprabenthos and WP2 samples (Fig 8f), as was the case for P. heterocarpus. In April we observed an increase in euphausiid average size (which reached a maximum of $3.5 \mathrm{~mm}$ $\mathrm{CL}$, notably at $650 \mathrm{~m}$, Fig 8f). Decapod abundances in the enivironment were not correlated with diet data, possibly for the reasons given above. The 2 peaks in mesopelagic fish abundance observed in P. martia stomach contents in November off Cabrera and in April off Sóller were related to the peak in mesopelagic fish (Fig. 8g), mainly Cyclothone braueri, obtained in zooplanktonic and suprabenthic samples. C. braueri is a small gonostomatid fish with low swimming ability (Cartes et al. 1994). In April, the maximum abundance of myctophids caught by trawling in Cabrera was correlated with the peak of mesopelagic fish in the diet. In this month, myctophids were mainly preyed on by $P$. martia.

In general, changes in feeding and diet of Plesionika heterocarpus, which also prey on benthic organisms, were less evident than in P. martia, a strictly benthopelagic feeder. This may imply that seasonal changes in the diet are due to larger seasonal fluctuations in pelagic prey compared with those of benthic prey. For $P$. heterocarpus, seasonal variability in abundance by depth occurred off Cabrera. The species was distributed in deepest waters (550 to $650 \mathrm{~m}$ ) from August to November, and it moved to shallower waters (250 to $350 \mathrm{~m}$ ) in April-June. This varying distribution pattern was probably influenced by warm, saline Levantine Intermediate Water (LIW), which occurred between 200 and $700 \mathrm{~m}$. Also, a positive correlation was found between MDS dimension 2 and salinity. During August and September 2003, an anticyclonic gyre was present in the Gulf of Valencia, which produced a branch of the BC (Balearic Current) flowing inside the Mallorca channel, with distinct WIW (Winter Intermediate Waters) and LIW values (Lopez-Jurado et al. 2008). Correlations with salinity close to the bottom suggest a link between shrimp abundance (increment in biomass in August-September) and changes in physicochemical conditions close to the bottom. These changes may be related to the occurrence of LIW in April-June off Sóller (López-Jurado et al. 2008).

As previously observed (Fanelli \& Cartes 2004) in the Alboran Sea, fullness was negatively correlated with state of maturity. As gonads increased in size, the shrimps decreased their feeding activity because the body cavity was completely occupied by the gonads and because the energetic requirements decrease once the gonads are fully developed. Moreover, fullness was negatively correlated with depth; feeding activity was higher in the optimal range of the shallower Plesionika heterocarpus between 250 and $350 \mathrm{~m}$. It then decreased below $600 \mathrm{~m}$. This general pattern has been reported previously (Cartes \& Abelló 1992, Fanelli \& Cartes 2004) and seems to be general for such species as an adaptation to the deep-sea environment, where trophic resources are scarce. Below $600 \mathrm{~m}$, the population is made up almost exclusively of ovigerous females, and adults are located deeper than juveniles (Carbonell et al. 2003). This contrasts with the findings of Company \& Sardà (1997), who recorded a greater abundance of males in the deepest range (400 to $500 \mathrm{~m}$ in their case) of the species. Fullness was also correlated with time of sampling, and feeding activity of $P$. heterocarpus was higher between 09:00 and 10:00 h, probably due to the high consumption of pelagic resources in the Balearic basin. Pelagic resources show large diel vertical migrations (Roe 1974, Hargreaves 1984) and this may influence the feeding activity rhythms in deep-sea decapods. Among the environmental variables examined, mean grain size of sediment was significantly correlated with fullness, and this may be explained by the more benthic behaviour of this species and its predation on benthic organisms (e.g. polychaetes, tanaids). For P. martia, fullness was correlated with depth, temperature and the abundance of gelatinous plankton (e.g. Siphonophora) in the environment off Sóller, but not off Cabrera; this difference was probably due to the dissimilarity in oceanographic features observed in the 2 areas (Lopez-Jurado et al. 2008).

Changes in diet are coupled with changes in caloric content and with requirements for greater energy, as observed for a number of deep-sea species (Madurell $\&$ Cartes 2005, 2006). There is a general increase in seasonality of reproductive patterns with depth in pandalid shrimps (Company \& Sardà 1997); maximum abundance of mature females in Plesionika martia occurred in summer, while in $P$. heterocarpus there was a more continuous reproductive pattern.

Based on the caloric content data presented here (see Madurell \& Cartes 2005, T. Madurell unpubl. data), Plesionika martia seemed to prefer high caloric content prey in spring-summer (e.g. euphausiids and mesopelagic fish), just before the peak in mature females (Maiorano et al. 2002, Fanelli et al. 2004, present study: Fig. 5b). Thus, the higher energetic requirements of $P$. martia for reproduction in summer seem to be met by an increase in the caloric content of its diet, which is different from the pattern in some deep-sea fishes such as Hoplostethus mediterraneus in the Ionian sea (Madurell \& Cartes 2005) and 3 bathyal and abyssal macrourids (Coryphaenoides spp.) in the NE Pacific (Drazen 2002).

Isotopic results confirmed some trends observed in stomach content data. When comparing isotopic ${ }^{13} \mathrm{C}$ in both species, the most depleted values were found (on average) in Plesionika martia, the species in which 
diet was more based on pelagic prey. This is consistent with more depleted signatures found in planktonic diets (Polunin et al. 2001). Species enriched in ${ }^{13} \mathrm{C}$ are categorized as the 'benthic carnivore group' into which Plesionika heterocarpus falls (as well as preying on macrozooplankton, the species takes benthic prey items such as polychaetes and tanaids). Marine snow was the single food source for benthopelagic and megafaunal communities in open areas of the Algerian Basin (Polunin et al. 2001), an oligotrophic open-sea area where benthos is scarce. Bathyal communities are sustained by plankton more than by benthos in oligotrophic areas such as the Ionian Sea (e.g. Madurell \& Cartes 2005) and around the Balearic Islands, where river discharges, for instance, are minimal. Stomach contents showed a more planktonic diet in P. martia, the deeper species, In accordance with high fluctuations in planktonic prey availability, ${ }^{13} \mathrm{C}$ signatures changed more markedly over the year in $P$. martia than in $P$. heterocarpus. Our isotopic results on pandalids represent the first attempt to study temporal (bi-monthly) changes in deep-sea species. Hence, it is difficult to establish how changes in diet are reflected in the isotopic composition of tissues, because no data are available on $\mathrm{C}$ and $\mathrm{N}$ assimilation rates in deep sea organisms. Tissue turnover in Plesionika spp. must be slow because, in shallow water fish, tissue turnover times may be as low as 0.1 to $0.2 \% \mathrm{~d}^{-1}$ (Hesslein et al. 1993) and deepsea species normally have slower metabolic rates and tissue turnover than shallow-water species. In addition, different foods are assimilated at different rates in the gut, and the relative contributions to tissue production of dietary components such as gelatinous zooplankton are unknown. In summary, and in spite of the fact that it is not clear how isotope assimilation reflects changes in gut-content analysis, our results for $P$. martia suggests a quick response. Changes in diet were more evident from November-February to April for P. martia; this pattern is common to other deep-sea species in the area (i.e. Aristeus antennatus [Cartes et al. 2008], Hoplostethus mediterraneus [Fanelli 2007]). The lower availability of resources in the environment from late summer (September) to autumn (November) (Cartes et al. 2008; see also our Fig. 8) at depths inhabited by $P$. martia, may be responsible for lower feeding activity. Therefore, in the period September-February, pandalids may feed on prey which are themselves in a period of low productivity. In periods where respiration is higher than new production, more refractory materials (Mullerniklas et al. 1994) such as inorganic carbonates and chitin, which are known to be enriched in ${ }^{13} \mathrm{C}$ compared to other biochemical fractions (Bunn et al. 1995), occur; this, with some delay, could be reflected in the ${ }^{13} \mathrm{C}$ enrichment in $P$. martia tissues. Later, in April-June, the increase in production due to vertical fluxes of fresh POM or marine snow (e.g. in the Ligurian Sea, Miquel et al. 1994) may contribute to the observed ${ }^{13} \mathrm{C}$ depletion in $P$. martia muscle.

These considerations were also supported by $\delta^{15} \mathrm{~N}$ signatures. More depleted values were recorded in February, coupled (with some delay) with the decrease in $\delta^{15} \mathrm{~N}$ of the preferred prey Meganycthiphanes norvegica (7.2\%), Cyclothone braueri $(5.2 \%$ ) and the bulk of suprabenthic $(7.3 \%$ ) and zooplanktonic $(5.7 \%$ o) species off Cabrera between November and February (Fanelli 2007). Off Sóller the most depleted $\delta^{15} \mathrm{~N}$ value was observed in November, coupled with the lower $\delta^{15} \mathrm{~N}$ values of Nematoscelis megalops $(6.8 \%), C$. braueri $(7.0 \%$ ) and the bulk of suprabenthic species (6.4\%) observed in September (Madurell et al. 2008).

A last possible explanation for the large $\delta^{13} \mathrm{C}$ variation observed in February may be linked to the reproductive pattern of Plesionika martia. There are reports that pandalids (Thessalou-Legaki et al. 1989, Puig et al. 2001) and other families inhabiting the uppermiddle slope (Morales-Nin et al. 2003) undergo a continuous ontogenetic migration towards deeper waters (bigger-deeper trend). In addition, there is a tendency towards size segregation with depth for males and non-ovigerous females in contrast to ovigerous females, indicating that females move to deeper waters before egg release, then cease their migratory activity when berried (Chilari et al. 2005). Polunin et al. (2001) found more enriched $\delta^{13} \mathrm{C}$ signatures in benthopelagic fauna with increasing depth from upper to lower slope. As a consequence, during pre-reproductive migration when $P$. martia moves deeper (in late autumn-early winter), it may move from a more depleted to a more enriched $\delta^{13} \mathrm{C}$ environment, hence the sharp increase in $\delta^{13} \mathrm{C}$ found in February 2004.

In conclusion, the deeper species $P$. martia showed stronger seasonal shifts in feeding, diet and reproductive cycle than the shallower species $P$. heterocarpus despite the bathymetric distribution range of the latter being closer to sources of primary production. The trophic role of the mesopelagic community of zooplankton-micronekton in the diet of $P$. martia seems to be the cause of this rather unexpected trend.

Acknowledgements. We greatly appreciate the help of all participants in the 'IDEA' cruises, to the crew of the R/V 'Francisco de Paula Navarro' and especially to our colleague M. Serra for his assistance on board. We also extend our thanks to J. Moranta and E. Massutí for their help in planning the cruises. We especially acknowledge the assistance of P. Rumolo and M. Sprovieri (CNR-IAMC of Naples) in the stable isotope analyses. We thank H. Main for revising the English. 


\section{LITERATURE CITED}

Abelló P, Valladares FJ, Castellon A (1988) Analysis of the structure of decapod crustacean assemblage off the Catalan coast (North-Western Mediterranean). Mar Biol 98:39-49

Anderson MJ (2001) A new method for non-parametric multivariate analysis of variance. Aust Ecol 26:32-46

Angel MV (1990) Life in the benthic boundary layer: connections to the mid-water and sea floor. Philos Trans R Soc Lond 331:15-28

Arai MN (2005) Predation on pelagic coelenterates: a review. J Mar Biol Assoc UK 85:523-536

Blaber SJM, Bulman CM (1987). Diets of fishes of the upper continental slope of eastern Tasmania: content, calorific values, dietary overlap and trophic relationships. Mar Biol 95:345-356

Bunn SE, Loneragan NR, Kempster MA (1995) Effects of acid washing on stable isotope ratios of $\mathrm{C}$ and $\mathrm{N}$ in penaeid shrimp and seagrass: implication for food web studies using multiple stable isotopes. Limnol Oceanogr 40:622-625

Carbonell A, Abelló P (1998) Distribution characteristics of pandalid shrimps (decapoda: Caridea: Pandalidae) along the Western Mediterranean Sea. J Nat Hist 32:1463-1474

Carbonell A, Palmer M, Abelló P, Torres P, Alemany R, Gil de Sola L (2003) Mesoscale geographical patterns in the distribution of pandalid shrimps Plesionika spp. in the Western Mediterranean. Mar Ecol Prog Ser 247:151-158

Cartes JE (1993) Diets of deep-water pandalis shrimps on the western Mediterranean slope. Mar Ecol Prog Ser 96:49-61

Cartes JE, Abelló P (1992) Comparative feeling habits of polychelid lobsters in the western Mediterranean deep-sea communities. Mar Ecol Prog Ser 84:139-150

Cartes JE, Company JB, Maynou F (1994) Deep-water decapod crustacean communities in the northwestern Mediterranean: influence of submarine canyons and season. Mar Biol 120:221-229

Cartes JE, Abelló P, Lloris D, Carbonell A, Torres P, Maynou F, Gil De Sola L (2002) Feeding guilds of western Mediterranean demersal fish and crustaceans: an analysis based on a spring survey. Sci Mar 66 (Suppl 2):209-220

Cartes JE, Rey J, Lloris D, Gil de Sola L (2004) Influence of environmental variables in the feeding and the diet of European hake (Merluccius merluccius) on the Mediterranean Iberian coasts. J Mar Biol Assoc UK 84:831-835

Cartes JE, Madurell T, Fanelli E, López-Jurado JL (2008) Dynamics of suprabenthos-zooplankton communities around the Balearic Islands (NW Mediterranean): influence of environmental variables and effects on higher trophic levels. J Mar Syst (in press)

Chilari A, Thessalou-Legaki M, Petrakis G (2005) Population structure and reproduction of the deep-water shrimp Plesionika martia (Decapoda: Pandalidae) from the eastern Ionian sea. J Crust Biol 25:233-241

Clarke KR, Warwick RM (1994) Change in marine communities: an approach to statistical analysis and interpretation. Natural Environment Research Council, Plymouth

Company JB, Sardà F (1997) Reproductive patterns and population characteristics in five deep-water pandalid shrimps in the Western Mediterranean along a depth gradient (150-1100 m). Mar Ecol Prog Ser 148:49-58

Crosnier A, Forest J (1973) Les crevettes profondes de l'Atlantique oriental tropical. Faune Trop 19:1-409

Davis (1993) Caloric content of oceanic zooplankton and fishes for studies of salmonid food habits and their ecologically related species. (NPAFC Doc. 15) FRI-UW-9312. Fisheries Research Institute, University of Washington,
Seattle, WA

Drazen JC (2002) Energy budgets and feeding rates of Coryphaenoides acrolepis and C. armatus. Mar Biol 140: 677-686

Fanelli E (2007) Trophic relationships in demersal communities of western Mediterranean: case studies from coastal and deep-sea ecosystems. PhD Thesis, University of Viterbo

Fanelli E, Cartes JE (2004) Feeding habits of pandalid shrimps in the Alboran sea (SW Mediterranean): influence of biological and environmental factors. Mar Ecol Prog Ser 280: $227-238$

Fanelli E, Belluscio A, Colloca F, Ardizzone GD (2004) Distribution characteristics of pandalid shrimps (Decapoda: Caridea: Pandalidae) along the central Mediterranean sea. Med Mar Sci 5:35-43

Gordon JDM (1979) Lifestyle and phenology in deep sea anacanthine teleosts. Symp Zool Soc Lond 44:327-359

Hargreaves PM (1984) The distribution of Decapoda (Crustacea) in the open ocean and near-bottom over an adjacent slope in the northern north-east Atlantic Ocean during autumn 1979. J Mar Biol Assoc UK 64:829-857

Hellawell JM, Abel R (1971) A rapid volumetric method for the analysis of the food of fishes. J Fish Biol 3:29-37

Hesslein RH, Hallard KA, Ramlal P (1993) Replacement of sulfur, carbon and nitrogen in tissue of growing broad Whitefish (Coregonus nasus) in response to a change in diet traced by $\delta^{34} \mathrm{~S}, \delta^{13} \mathrm{C}$ and $\delta^{15} \mathrm{~N}$. Can J Fish Aquat Sci 50:2071-2076

Holthuis LB (1980) FAO species catalogue, Vol 1 Shrimps and prawns of the world. An annotated catalogue of species of interest to fisheries. FAO Fish Synop 125:1-271

Howell KL, Pond DW, Billett DSM, Tyler PA (2003) Feeding ecology of deep-sea seastars (Echinodermata: Asteroidea): a fatty-acid biomarker approach. Mar Ecol Prog Ser 255: 193-206

Hyslop EJ (1980) Stomach contents analysis - a review of methods and their application. J Fish Biol 17:411-429

Keisuke S (2004) Occurrence of Phronima sedentaria (Forskål, 1775) (Amphipoda, Hyperiidea) in the stomach of the longnose lancetfish, Alepisaurus ferox (Lowe, 1833) (Aulopiformes, Alepisauroidei) in the North and tropical Atlantic Ocean. Crustaceana 77:729-739

King MG, Moffitt RB (1984) The sexuality of tropical deepwater shrimps (Decapoda: Pandalidae) J Crust Biol 4: $567-571$

Labropoulou M, Kostikas I (1999) Patterns resource use in deep-water decapods. Mar Ecol Prog Ser 184:171-182

Lagardére JP (1972) Recherches sur l'alimentation des crevettes bathypelagiques du talus Continentale de la Pente Continentale Marocaine. Tethys 3:655-675

Lagardére JP (1977) Recherches sur la distribution verticale et sur l'alimentation des crustaces decapodes benthiques de la Pente Continentale du Golfe de Gascogne. Analyse des groupements carcinologiques. Bull Cent Etud Rech Sci Biarritz 11:367-440

López-Jurado JL, Marcos M, Monserrat S (2008) Hydrographic conditions during the IDEA project (2003-2004). J Mar Syst (in press)

Macpherson E (1981) Resource partitioning in a Mediterranean demersal fish community. Mar Ecol Prog Ser 4: 183-193

Madurell T, Cartes JE (2005) Temporal changes in feeding habits and daily rations of Hoplostethus mediterraneus, Cuvier, 1829 in the bathyal Ionian Sea (eastern Mediterranean). Mar Biol 146:951-962

Madurell T, Cartes JE (2006) Trophic relationships and food consumption of slope dwelling macrourids from the 
bathyal Ionian Sea (eastern Mediterranean). Mar Biol 148:1325-1338

Madurell T, Fanelli E, Cartes JE (2008) Isotopic composition of carbon and nitrogen of suprabenthos fauna in the NW Balearic Islands (Western Mediterranean). J Mar Syst (in press)

Maiorano P, D'Onghia G, Capezzuto F, Sion L (2002) Lifehistory traits of Plesionika martia (Decapoda: Caridea) from the eastern-central Mediterranean Sea. Mar Biol 141: $527-539$

Maynou F, Cartes JE (2000) Community structure of bathyal decapod crustacean assemblages off the Balearic islands (south-western Mediterranean). J Mar Biol Assoc UK 80: 789-798

Miquel JC, Fowler SW, La Rosa J, Buat-Menard P (1994) Dynamics of the down-ward flux of particles and carbon in the open northwestern Mediterranean sea. Deep-Sea Res I 41:243-261

Morales-Nin B, Maynou F, Sardá F, Cartes J and others (2003) Size influence in zonation patterns in fishes and crustaceans from deep-water communities of the western Mediterranean. J Northwest Atl Fish Sci 31:413-430

Mullerniklas G, Schuster S, Kaltenboch E, Herndl GJ (1994) Organic content and bacterial metabolism in amorphous aggregations of the Northern Adriatic Sea. Limnol Oceanogr 39:58-68

Polunin NVC, Morales-Nin B, Pawsey WE, Cartes JE, Pinnegar JK, Moranta J (2001) Feeding relationships in Mediterranean bathyal assemblages elucidated by stable nitrogen and carbon isotope data. Mar Ecol Prog Ser 220:13-23

Editorial responsibility: Matthias Seaman,

Oldendorf/Luhe, Germany
Post DM (2002) Using stable isotopes to estimate trophic position: models, methods, and assumptions. Ecology 83(3): 703-718

Puig P, Company JB, Sardá F, Palanques A (2001) Responses of deep-water shrimp populations to intermediate nepheloid layer detachments on the Northwestern Mediterranean continental margin. Deep-Sea Res Part I 48:2195-2207

Roe HSJ (1974) Observations on the diurnal vertical migrations of an oceanic animal community. Mar Biol 28:99-113

Sánchez, F, Cartes JE, Olaso I, Velasco F and others (2006) Monitoring the Prestige oil spill impacts on some key species of the Northern Iberian shelf. Mar Poll Bull 53: 332-349

Thessalou-Legaki M, Frantzis A, Nassiokas K, Hatzinikolau S (1989) Depth zonation in a Parapandalus narvalus (Crustacea, Decapoda, Pandalidae) population from Rhodos Island, Greece. Estuar Coast Shelf Sci 29:273-284

Underwood AJ (1997) Ecological experiments: their logical design and interpretation using analysis of variance. Cambridge University Press, Cambridge

Vander Zanden MJ, Cabana G, Rasmussen JB (1997) Comparing trophic position of freshwater fish calculated using stable nitrogen isotope ratios $\left(\delta^{15} \mathrm{~N}\right)$ and literature dietary data. Can J Fish Aquat Sci 54:1142-1158

Welch DW (1997) Anatomical specialization in the gut of Pacific salmon (Oncorhynchus): evidence for oceanic limits to salmon production? Can J Zool 75:936-942

Wormuth JH (1985) Net sampling of the zooplankton and krill in and around Elephant Island. Antarct J US 19(5):1-136

Submitted: April 25, 2007; Accepted: September 19, 2007

Proofs received from author(s): February 5, 2008 